\title{
DEVELOPMENT OF PROBLEM POSING LEARNING TOOLS TO IMPROVE MATHEMATICAL REASONING ABILITY AND SELF EFFICACY OF CLASS VIII STUDENTS OF SMP NEGERI 2 BANGKINANG KOTA
}

\author{
Rian Agusmar ${ }^{1 *}$, Bornok sinaga ${ }^{1}$, Elmanani Simamora ${ }^{1}$ \\ ${ }^{1}$ Department of Mathematics, Science Faculty, State University of Medan, J1. William Iskandar Ps. V, Kenangan \\ Baru, Sumatera Utara Indonesia \\ *E-mail of the corresponding author: Rian.agusmar@gmail.com
}

\begin{abstract}
This study aims to: 1) To analyze the increase in mathematical reasoning ability of SMP Negeri 2 Bangkinang Kota students taught by the problem posing learning device developed 2) To analyze the increase in self-efficacy of SMP Negeri 2 Bangkinang Kota students taught by the problem posing learning device developed 3) To analyze the effectiveness of problem posing learning devices developed to improve mathematical reasoning and self-efficacy abilities of SMP Negeri 2 Bangkinang Kota 4) students to analyze the practicality of problem posing learning devices developed to improve mathematical reasoning abilities and self-efficacy of state junior high school students 2 Bangkinang City. The subjects in this study were students of SMP Negeri 2 Bangkinang Kota in class VIII-1 with 27 students and VIII-2 with 29 students. The results showed that: 1. Improvement of students 'mathematical reasoning abilities using the problem posing learning tool on the material of the Two Variable Linear Equation System (SPLDV) was the average achievement of students' mathematical reasoning abilities in the first try of 71.60 increasing to 78.71 in the trials II. 2. Increasing students' self-esteem from trial I to trial II using the problem posing learning device for each student motivation indicator including: (1) experience of success, where in trial I with an average of 27.80 while in the test try II with an average of 27.86 , an increase of 0.06; (2) Indicators of other people's experiences, where in trial I with an average of 27.56, while in trial II amounted to 27.98, an increase of 0.42 ; (3) Indicators of social approach, in trial I with an average of 28.17 and an average in trial II of 28.18, experienced an increase of 0.01; and (4) Indicators of psychological and emotional state in trial I with an average of 26.13 and an average in trial II of 26.32, an increase of 0.19.
\end{abstract}

Keywords : mathematical reasoning abilities, problem posing learning, self-efficacy, mathematics learning tools DOI: $10.7176 / \mathrm{JEP} / 10-33-17$

Publication date: November $30^{\text {th }} 2019$

\section{Introduction}

The development of science and technology in the 21 st century is growing rapidly. In addition to rapid development, changes also occur quickly. If not balanced properly, Indonesia will be left behind by other countries. Many things underlie it, one of which is the current of globalization which is getting stronger and more open. Education is one of the means and tools so that Indonesia is not left behind from other countries. This is in accordance with Primary, et al (2013: 335) "Education is the upholding pillar of the nation. It is through education that the nation will be able to maintain its dignity ". Education has become a pillar in increasing Indonesia's human resources for nation building.

There are many reasons for the importance of studying mathematics because of its many uses, both as a science, as a tool, and as an expected attitude maker. Here are some of the uses of learning mathematics according to Cornelius in Abdurrahman (2012: 204): "Five reasons for the need to learn mathematics because mathematics is (1) a clear and logical means of thinking, (2) a means for solving problems of daily life, (3) a means of recognizing patterns of relationships and generalizing experiences, (4) a means for developing creativity, and (5) a means for raising awareness of cultural development ".

However, a serious problem in the academic achievement of students in Indonesia is the low quality of education. Especially in learning mathematics, students view mathematics as a difficult subject. According to Saragih and Habeahan (2014: 123) "this happens because of the mathematics presented in a form that is less appealing and seems difficult for students to learn; as a result students often feel bored and don't respond well lesson ". The essence of the statement is mathematics presented in a minimal form of application and difficult to learn so that students feel bored and do not give positive responses. National Councils of Teachers of Mathematics (NCTM) (Gunhan, 2014: 1) suggested that "Reasoning skills are an important component of education, and reasoning skills are necessary for understanding mathematics in particular, and the present an important meaning of developing ideas". Reasoning ability is interpreted as an important component in education, needed when understanding mathematics and developing ideas. 
In addition to seeing the importance of students 'mathematical reasoning abilities in learning, another aspect that needs to be developed is students' self-efficacy. Bandura (1998: 2) defines self-efficacy as one's beliefs about their ability to produce performance that has an influence on their lives. Self-efficacy determines how a person feels, thinks, motivates himself and behaves. Self-efficacy has a relationship with achievement and motivation student.

One learning model that can encourage students' mathematical reasoning abilities and self-efficacy is Problem Posing. Problem Posing is an alternative that allows promising ability to play a role in improving students' mathematical reasoning abilities and self-efficacy. According to Wulandari (Persada, 2014, p. 33) problem posing comes from English which means "formulate a problem (problem)" or raise a problem. According to Nurafifah (201, p.159) problem posing is a model in learning by giving assignments to students to design or make questions based on the conditions presented and solve the problem. Circumstances can take the form of pictures, stories, or other explanations related to the subject matter.

Problem posing by Akay and Boz (2010: 2) is defined as the process of thinking when students participate in the formulation of problems and also when students form new problems or questions. Problem posing learning in collaboration with learning cell techniques allows students to learn effectively in small groups ( 2 people). In this technique, one of the students raised a problem with the student's partner and carried out alternately. In this situation there will be a process of discussion between students so that they can add insight and skills, as well as in improving students' mathematical reasoning abilities and self-efficacy. From the description of the problems above, the researcher concludes that it needs a research that is related to students' mathematical reasoning abilities and self-efficacy as well as its relation to the existence of mathematical learning tools.

\section{Methods}

\section{Research Pattern}

Based on the stated research objectives, this research is categorized into a type of development research. This study uses the 4-D development model of Thiagarajan, Semmel and Semmel (1974) by developing Problem Posing learning tools. The learning tools developed are Teacher's Book (BG), Student's Book (BS), Student Activity Sheet (LAS) and research instruments namely tests of mathematical reasoning ability and student's selfefficacy.

\section{Participants}

The subjects in this study were students of SMP Negeri 2 Bangkinang Kota class VIII-1 with 27 students and VIII-2 with 29 students.

\section{Data Collection Technique}

The tool used to collect data to determine the level of mathematical reasoning ability of students is the description test. Mathematical mathematical reasoning ability test (TKPM), is used to obtain information about students' mastery of the topic circle after being given a learning device with problem posing done. The test is given at the end of the learning meeting and the test instrument is developed by the researcher himself.

\section{Validity and Reliability}

The learning device validation sheet is used to obtain data about the quality of the learning kit based on expert judgment. Some validation sheets that are used include: (a) The validation sheet of the lesson plan (RPP), (b) The validation sheet of the Student Activity sheet (LAS), (c) the validation sheet of student books (BS), and (d) the book validation sheet teacher (BG). This validation sheet contains the assessed components including: format, language, illustrations, and content.

\section{Data Analysis}

The data analysis technique used in this research is descriptive analysis. The data obtained were analyzed and directed to answer the question whether the learning device with the developed Problem Posing learning model meets the criteria of validity and effectiveness or not. Data obtained from expert or practitioner teams are analyzed and directed to answer whether the learning tools developed have met the validity criteria. While the trial data in the field is used to answer whether the learning tools developed have met the effectiveness criteria or not.

\section{Result and Discussion}

This research is a research development (development research), so the product of this study is a posing problem learning device. The purpose of this development research is to find out: (1) improvement of students' mathematical reasoning abilities through the use of developed problem posing learning tools; (2) improvement of students' self-efficacy through the use of developed posing problem learning tools; (3) validity, practicality, and effectiveness of the problem posing learning tools developed. 
1) Description of Improvement of Mathematical Reasoning Ability Students use the developed problem posing learning tool

Data obtained from the results of the posttest of students 'mathematical reasoning abilities in the first and second trials were analyzed to find out the improvement in students' mathematical reasoning abilities by comparing the average scores of students obtained from the posttest results of the mathematical reasoning abilities of the students of I and II. Descriptions of increasing students' mathematical reasoning abilities using problem posing learning tools developed in trials I and II are shown in Table 1.

Table 1. Description of Results of Mathematical Reasoning Ability

\begin{tabular}{|c|c|c|}
\hline Information & $\begin{array}{c}\text { Posttest Mathematical } \\
\text { Reasoning Trial I }\end{array}$ & $\begin{array}{c}\text { Posttest Mathematical } \\
\text { Reasoning Trial II }\end{array}$ \\
\hline The highest score & 87 & 91 \\
\hline The Lowest Value & 40 & 69 \\
\hline Average & $\mathbf{7 1 , 6 0}$ & 78,71 \\
\hline
\end{tabular}

Based on Table 1, the results of the analysis of increasing students' mathematical reasoning abilities in the first try and the second try showed that the average mathematical reasoning of the students on the results of the first try posttest was 71.60 increased to 78.71 in the second tryout.

Furthermore, a description of the improvement in students 'mathematical reasoning abilities using the problem posing learning tool developed in Trial I and Trial II for each indicator of students' mathematical reasoning can be seen in Table 2 below.

Table 2. Average Mathematical Reasoning Ability of Students

\begin{tabular}{|lcc|}
\hline \multicolumn{1}{|c|}{ Mathematics Reasoning Indicator } & \multicolumn{2}{c|}{ Average } \\
\cline { 2 - 3 } & Trial I & Trial II \\
\hline Menyajikan Pernyataan Matematika & 75,9 & 81,6 \\
\hline Submitting an estimate & 66,5 & 75,2 \\
\hline $\begin{array}{l}\text { Compile evidence, provide reasons / evidence for the } \\
\text { correctness of the solution }\end{array}$ & 70,9 & 75,5 \\
\hline Checking the validity of an argument & 73,1 & 81,4 \\
\hline Draw conclusions from statements & 72,8 & 83,3 \\
\hline
\end{tabular}

2) Description Improved Self-efficacy Students use the developed problem posing learning tool

Based on the results of trial I and trial II obtained the results of student self-efficacy questionnaire. The questionnaire was given at the end of each meeting aimed at looking at students' self-efficacy. data obtained from the results of the self-efficacy questionnaire of trial I and trial II were analyzed to find out the increase in students' self-efficacy by comparing the average score of students obtained from the results of the self-efficacy questionnaire of trial I and trial II. Description of the increase in students' self-efficacy after the application of the problem posing learning tool developed is shown in Table 3 below.

Table 3. Average Student Self-efficacy

\begin{tabular}{|l|l|c|c|}
\hline \multirow{2}{*}{ No } & \multirow{2}{*}{ Self-efficacy indicator } & \multicolumn{2}{|c|}{ Average of each Indicator } \\
\cline { 3 - 4 } & & Trial I & Trial II \\
\hline 1 & Experience of success & 27,80 & 27.86 \\
\hline 2 & Other people's experiences & 27,56 & 27,98 \\
\hline 3 & Social approach & 28,17 & 28,18 \\
\hline 4 & Psychological and emotional state & 26,13 & 26,32 \\
\hline \multicolumn{2}{|c|}{ Average Total of All Indicators For Each Trial } & 2.75 & 2.82 \\
\hline
\end{tabular}


Table 3. shows that, the improvement of each indicator of students' mathematical reasoning ability, namely in the first try, namely the average mathematical reasoning ability on the indicators of presenting mathematical statements is 75.9 , the indicators presenting allegations is 66.5 , the indicators compiling evidence and giving reasons / proof of the correctness of the solution is 70.9 , the indicator Checking the validity of an argument is 73.2 , and the indicator drawing conclusions from the statement is 72.8 . In the second trial, the average mathematical reasoning ability on the indicators of presenting mathematical statements was 81.6 , on the indicators of presenting allegations was 75.2, the indicators Constructing evidence and giving reasons / proof of the correctness of the solution was 75.5 , the indicator Checking the validity of a argument is 81.5 , and the indicator draw conclusions from the statement is 83.3.

Based on Table 3. above, it can be concluded that the average results of students' self-efficacy questionnaires increased from the results of trial I to trial II, namely in trial I by 2.75 while in trial II by 2.82 and experienced an increase of 0.07 . While the average score of each indicator is also an increase from trial I to trial II. Each average score of each indicator in the first trial increased to the second trial, namely: (1) experience of success, where in the first trial with an average of 27.80 while the second trial with an average of 27.86 , an increase of 0.06 ; (2) Indicators of other people's experiences, where in trial I with an average of 27.56, while in trial II amounted to 27.98 , an increase of 0.42 ; (3) Indicators of social approach, in trial I with an average of 28.17 and an average in trial II of 28.18, experienced an increase of 0.01 ; and (4) Indicators of psychological and emotional state in trial I with an average of 26.13 and an average in trial II of 26.32, an increase of 0.19.

Based on the above results it can be concluded that the students' self-efficacy after the application of the problem posing learning device that was developed increased from trial I to trial II.

\section{Discussion}

1) Improving Students' Mathematical Reasoning Abilities by Using Problem Posing Learning Tools

Based on the results of an analysis of increasing mathematical reasoning abilities in the first try and the second trial showed that the average mathematical reasoning ability of students on the posttest results of the first try of 71.6 increased to 78.71 in the second trial. Thus, an increase in the average value of students' mathematical reasoning abilities was 7.11. Furthermore, an increase in each indicator of students' mathematical reasoning ability is an increase in the average mathematical reasoning ability of students on the indicator presents a mathematical statement of 5.7, on the indicator of submitting an allegation of 8.7 , on the indicator of compiling evidence and giving reasons for a solution of 4,6 , the indicator checks the validity of an argument of 8.3 , and the indicator draws a conclusion of 10.5. This shows the mathematical reasoning ability of students using the problem posing learning device developed has increased from trial I to trial II.

This is because with the presentation of contextual problems as a starting point for the learning process, it can make students more active in producing and constructing their knowledge through the creation of mathematical models. The mathematical models as a form of representation of the problems needed in order to facilitate in solving contextual problems. With this model both informal and formal, students can find their own concepts or mathematical procedures that are learned.

Effandi Zakaria and Muzakkir Syamaun's research results (2017) state that RME brings students to the real world from everyday experiences can improve students' understanding of abstract mathematical concepts, RME also helps students solve mathematical problems at a higher level so as to improve student learning achievement and Syahputra and Surya's (2017) research results show that the use of learning tools can improve students' high-level thinking skills. With the same research conducted by Azlina Lubis (2018) said that the development of teaching materials based on realistic mathematical approaches can improve students' mathematical reasoning abilities and emotional intelligence.

Thus it can be understood that given contextual problems can be used as a starting point in developing students' mathematical reasoning abilities, especially in writing. Furthermore, discussion as a bridge helps each other between students who are lacking with students who are better at understanding the given model. So it can be concluded that the problem posing learning device developed has a positive impact on increasing mathematical reasoning ability.

\section{2) Improvement of Student's Self-efficacy by Using Posing Problem Learning Tools}

Based on the results of the analysis of students' self-efficacy questionnaires in trial I was 2.75 increased to 2.82 in trial II. An increase in the average value of 0.07. Likewise for each student's self-efficacy indicator, it appears that the indicator of psychological and emotional state is the lowest indicator, 0.19 .

This was reinforced through the results of Kartika's research (2015: 13) which showed that there were differences in the increase in self-efficacy between students who were taught mathematics through a realistic mathematics approach and students who were given normal learning. According to Suci (2018) the average value of self-efficacy indicators with problem-based learning is an indicator of the experience of success 0.08 ; the experience of others 0.57; social approach 0.89; and psychological and emotional state 0.29. 
It can be concluded from the results of several studies above that the lowest average percentage is in the psychological and emotional state indicators, it can be seen that the results of research by researchers are lower on these indicators. This is due to lack of self-confidence and lack of confidence in students with their own abilities. So it can be concluded that the developed problem posing learning tool can improve student selfefficacy.

\section{Conclusion}

1. Improvement of students 'mathematical reasoning abilities using problem posing learning devices in the material of the Two Variable Linear Equation System (SPLDV) is the average achievement of students' mathematical reasoning abilities in trial I by 71.60 increasing to 78.71 in trial II. In addition, the average of each indicator of mathematical reasoning ability increased from trial I to trial II..

2. Increasing students' self-esteem from trial I to trial II using the problem posing learning device for each student motivation indicator including: (1) experience of success, where in trial I with an average of 27.80 while in the test try II with an average of 27.86, an increase of 0.06 ; (2) Indicators of other people's experiences, where in trial I with an average of 27.56, while in trial II amounted to 27.98, an increase of 0.42; (3) Indicators of social approach, in trial I with an average of 28.17 and an average in trial II of 28.18, experienced an increase of 0.01 ; and (4) Indicators of psychological and emotional state in trial I with an average of 26.13 and an average in trial II of 26.32, an increase of 0.19 .

3. The learning tools developed include RPP, Teacher's Book, Student's Book, LAS has been effective for use in learning, because it has met the effectiveness indicator of learning devices. The effectiveness indicators are:

a. Classical students' mastery learning in the first trial was $74.07 \%$ and the second trial was $89.66 \%$. This means that trial I has not been effective while trial II has been effective.

b. Achievement of learning objectives in trial I amounted to $74.07 \%$ and trial II amounted to $89.66 \%$. This means that the achievement of learning objectives for trial I and trial II was achieved..

c. The criterion of learning time is that the achievement of minimum learning time is the same as that of ordinary learning in trial I and trial II has been achieved. This means the learning time criteria are effective.

4. Student responses to the components of learning tools oriented to problem-based learning models that are developed and learning activities are positive.

\section{REFERENCES}

Abdurrahman, M. 2012. Children with Learning Difficulties: Theory, Diagnosis, and Remediation. Jakarta: Rineka Cipta.

Akker, J.V.D., dkk. 1999. Design Approaches and Tools in Education and Training. Kluwer Academic Publisher.

Bandura, A. (1998). Personal and collective efficacy in human adaptation and change. In J. G. Adair, D. Belanger, \& K. L. Dion (Eds.), Advances in psychological science: Vol. 1. Personal, social and cultural aspects (pp. 51-71). Hove, UK: Psychology Press.

Creswell, J. W. 2014. Educational Research: Planning, Conducting and Evaluating Quantitative and Qualitative Research. Boston: Pearson Education, Inc.

NCTM. 2000. Principle and Standard for school Mathematic. Reston,VA: NCTM

Pratama, N., Irdamurni., Zulmiyetri. 2013. The Effectiveness of Realistic Mathematics Learning to Improve the Ability to Recognize Space Building in Children with Light Developmental Disabilities. Jurnal Ilmiah Pendidikan Khusus. 2(2): 334-342.

Simanullang,A.Y \& Edi Surya. 2014. Efforts to Improve Students' Mathematical Reasoning Abilities through the Group Investigation Learning Model on Round Number Materials. Journal of Mathematics Education. 3(7):73-85.

Simanullang,A.Y \& Edi Surya. 2014. Upaya Meningkatkan kemampuan Penalaran Matematika Siswa melalui Model Pembelajaran Group Investigation pada Materi Bilangan Bulat. Jurnal Pendidikan Matematika. 3(7):73-85.

Slavin, R. E. 2006. Educational Psychology, Theories and Practice. Eighth Edition. Masschusetts: Allyn and Bacon Publishers. 
Yuliani, K. \& Saragih, S. 2015. The Development of Learning Devices Based Guided Discovery Model to Improve Understanding Concept and Critical Thinking Mathematically Ability of Students at Islamic Junior High School of Medan. Journal of Education and Practice. 6(24): 116-128.

Thiagarajan, S. Semmel, DS. Semmel, M. 1974. Instructional Development for Training Teachers of Exceptional Children. A Sourse Book. Indiana: Indiana University 